\title{
Influence of the longitudinal inclination on the speed on highways
}

\author{
Borislav Hristov* \\ Department of Engineering Sciences, University of Applied Sciences Berlin (HTW Berlin), Germany
}

\begin{abstract}
The main objective of the present paper is to investigate the influence of the longitudinal inclination of grades on the speed behavior on highways. For assessing this dependence, all uphill and downhill highway sections were considered separately in the two travel directions and the mean values of both $85^{\text {th }}$ and $15^{\text {th }}$ percentile speeds were calculated for each section. In order to take into account the free speed selection, all speed limited highway sections were excluded from the study. To investigate the speed changes as a function of the longitudinal inclination, the speed differences $V_{85}$ between the speeds at the end and the beginning of each individual ascending and descending section were calculated as well. The dependencies were assessed also using the "moving average" over the grades. Both methodological approaches show that the magnitude of the longitudinal inclination on uphill sections has a clear influence on the speed and on the speed differences. A significant reduction of the speed and a significant increase of the speed difference were established on ascending sections with slopes over $4 \%$. Furthermore, it was found that the length of the ascending grades also affects the speed differences $\Delta \mathrm{V}_{85}$, which increase considerably on longer uphill sections.
\end{abstract}

\section{Introduction}

Driving behavior can be understood as a uniform multi-layered control system, which in road traffic is referred to as Driver-Vehicle-Road ([1], [2]). This system is an ordered classification of influencing variables on the driving behavior. The driver reacts to external influences and road characteristics by changing the speed. Therefore, the speed parameter itself represents the best and most suitable evaluation criterion for driving behavior. Different road parameters have an effect on the speed behavior and one of them is the longitudinal inclination of the grades (Fig. 1). The increased fuel consumption on uphill sections at large longitudinal slopes leads to an increase in drivers' costs and results in higher pollutant emissions. Therefore, it is necessary to determine an optimal longitudinal slope and an optimal length of ascending sections to ensure a homogeneous driving behavior through a relative constant speed level, to reduce road users' costs and to lower the pollutant emissions.

\footnotetext{
* Corresponding author: Borislav.Hristov@HTW-Berlin.de
} 


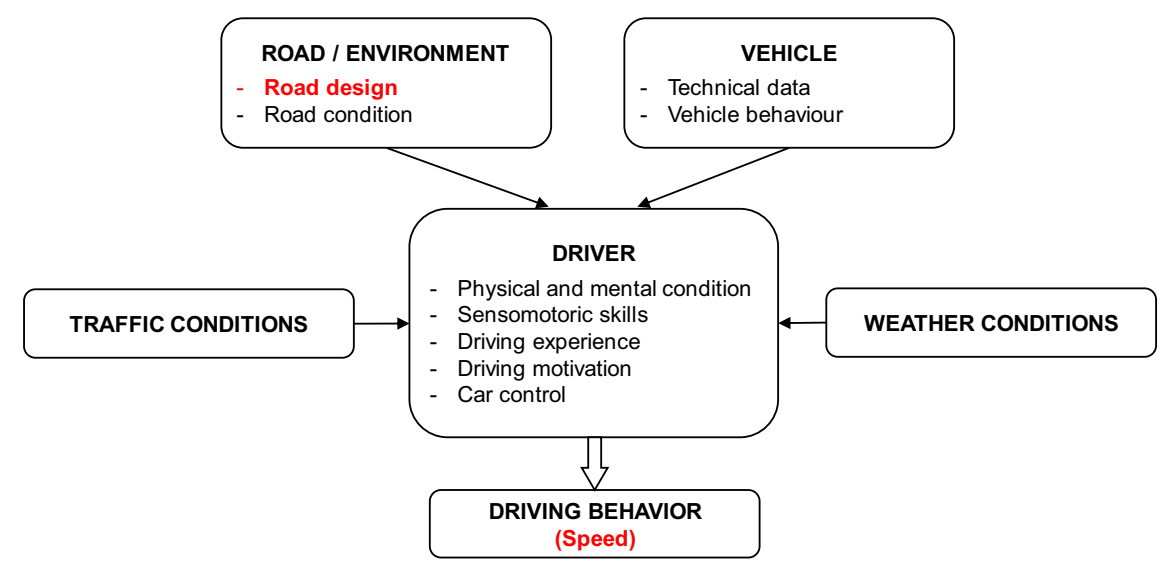

Fig. 1. Multi-layered control system Driver-Vehicle-Road.

For assessing the dependence between $85^{\text {th }}$ and $15^{\text {th }}$ percentile speeds and longitudinal inclination, all uphill and downhill highway sections have to be considered separately in both travel directions. The exact recording of the actual speed is important to be able to calculate the percentile speeds. A second possibility to investigate the effect of the longitudinal slope on the driving behavior is the method "moving average" over the grades.

The influence of longitudinal inclination on speed has been a subject of many research projects in the field of road design. On highways, however, only few such studies exist and there is a need for a research in this area.

\section{State of research}

In the literature there are very different opinions regarding the influence of the magnitude of longitudinal inclination on the speed on rural roads. It is noted that ascending slopes have positive values and descending slopes - negative ones. [3] writes that the speed on downhill grades depends on the mentality of the driver and higher speeds can be expected there. [4] states that the maximum route-characteristic speed is reached at $\mathrm{s}=-1.5 \%$ and the most favorable longitudinal inclination should be $\mathrm{s}= \pm 2 \%$. Three years later [5] report that the highest route-characteristic speed is achieved at small slopes under $-2 \%$. The speed decreases when the longitudinal gradient increases over 4\%. [6] find that longitudinal slopes in the range of $-4 \%<\mathrm{s}<+2 \%$ have a negligible influence on driving behavior. For these reasons, longitudinal inclination is not included as a research parameter in the work of [7]. [8] describe the dependence of local speeds on mean longitudinal inclinations with a quadratic function and find that mean longitudinal slopes between $-2 \%$ and $+2 \%$ do not influence the speed behavior.

In a study on highways, [9] finds that from all design parameters only the slope of the grades has an influence on the speed behavior. The author determines equations for longitudinal inclination ranges of $-3.5 \%<\mathrm{s}<+3.5 \%$. The respective speeds at different inclinations result from the speed profiles of the pursuit runs. The speed changes between the $\mathrm{V}_{15}, \mathrm{~V}_{50}$ and $\mathrm{V}_{85}$ at constant slopes increase with increasing gradient (Fig. 2). Since on downgrades the speed behavior does not depend on the performance of the vehicles, the speed changes are smaller and they are found to be only about $50 \%$ of the speed changes on upgrades. Due to the high performance of passenger cars in recent years, the speed has increased significantly. For this reason, the equations determined by [9] can no longer be regarded as up-to-date. 


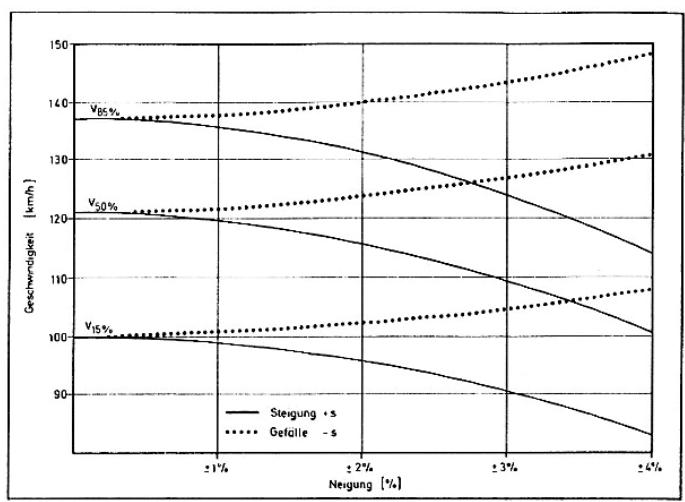

Fig. 2. Influence of different longitudinal inclinations (abscissa) on the speeds $\mathrm{V}_{85}, \mathrm{~V}_{50}$ and $\mathrm{V}_{15}$ (ordinate) on the highway A680 at dry conditions according to [9].

The authors also note that fast vehicles drive more unevenly and that the difference between fast $\left(\mathrm{V}_{85}\right)$ and slow $\left(\mathrm{V}_{15}\right)$ vehicle's speeds increases with increasing ascending slopes. Fig. 3 shows that the longitudinal inclination has a strong influence on the speed behavior on highways. It is concluded that the speed decrease percentage on uphill grades is approximately directly proportional to the square of the ascending slope. In contrast, the increase in speed on downhill grades is approximately proportional to half the square of the gradient.

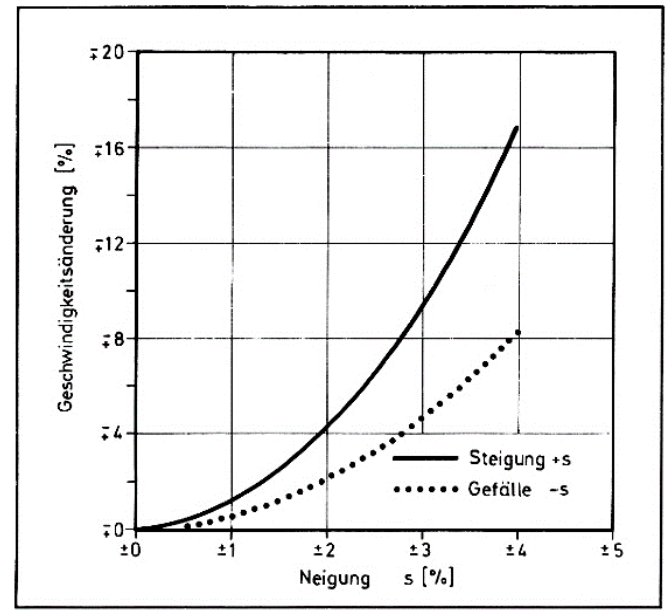

Fig. 3. Speed changes in \% (ordinate) of free-moving passenger cars on the A680 motorway as a function of longitudinal inclination in \% (abscissa) on uphill and downhill gradients according to [10].

Other authors have also determined dependencies between longitudinal inclination and driving behavior ([10], [11], [12]). From the studies of [13] and [14] it becomes clear that the speed reduction on uphill grades depends not only on the inclination magnitude but also on the length of the uphill grade. The course of the 50\% speeds of cars and trucks with and without trailers at different lengths is shown in Fig. 4. These speeds were measured on the motorway from the Ruhr area to Hanover on a section with $4 \%$ inclination with a length of $1700 \mathrm{~m}$ [9]. It can be seen that the speeds of passenger cars on ascending grades are significantly less influenced than the average speeds of the heavy traffic. 


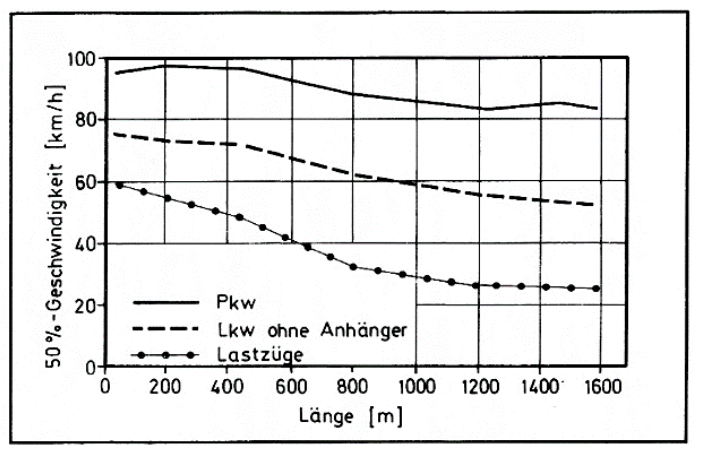

Fig. 4. Decrease in speed $V_{50}[\mathrm{~km} / \mathrm{h}]$ (abscissa) of free-moving vehicles on differently long gradients (ordinate) with $\mathrm{s}=4 \%$ according to [9] $(\mathrm{Pkw}=$ cars, Lkw ohne Anhänger $=$ truck without trailer, Lastzüge $=$ road trains).

[15] use the relative difference between the speeds of cars and trucks aiming to define the critical speed difference in order to determine the maximum length of grades on rural roads. The relative difference is limited to a predetermined threshold value $\Delta \mathrm{Vcr}$. The authors suggest the use of "critical grades" for various speeds and limit the length of the slopes which are steeper than the values of the "critical grades" (Fig. 5). They develop a criterion for a combination of length and slope, so that the maximum difference between the speed of cars and trucks should be less than a given threshold. This threshold depends on the design speed and the rate of slope $(0 \%, 1 \%, 2 \%$ and $3 \%)$.
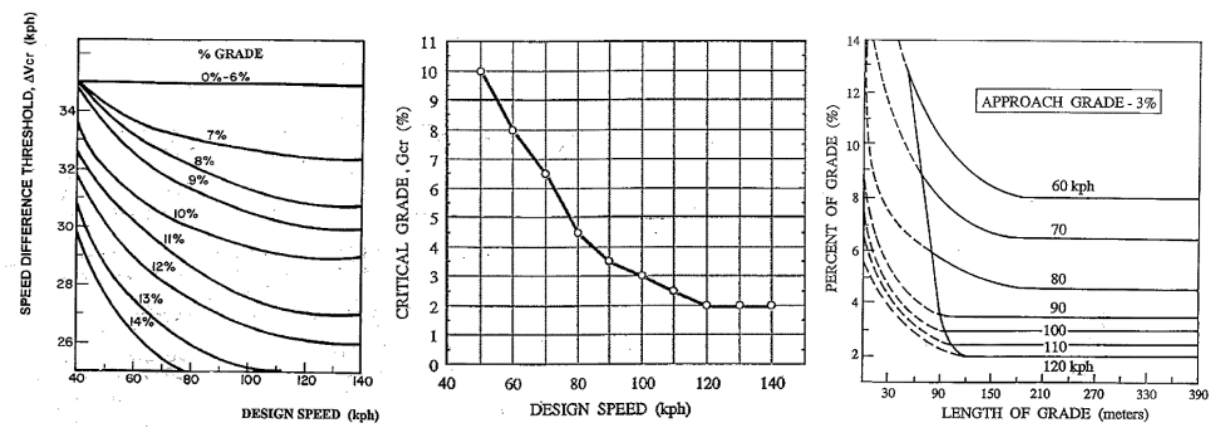

Fig. 5. Values of $\Delta V \mathrm{~V}$ r for various design speeds and percent grade (a), change in critical grades according to the design speed (b) and an example with a maximum length of grade (3\%) for various design speeds (c).

[16] also estimate the critical length of ascending grades on two-lane rural roads and compare them to the values in AASHTO (2011) and in MOP (2014) for higher speed reductions (Fig. 6).

\begin{tabular}{||c|c|c|c|c||}
\hline \multirow{2}{*}{$i \%$} & \multicolumn{2}{|c|}{ AASHTO (2011) } & \multicolumn{2}{c||}{ Este estudio/This study } \\
\cline { 2 - 5 } & $\Delta \mathrm{V}=15 \mathrm{~km} / \mathrm{h}$ & $\Delta \mathrm{V}=25 \mathrm{~km} / \mathrm{h}$ & $\Delta \mathrm{V}=15 \mathrm{~km} / \mathrm{h}$ & $\Delta \mathrm{V}=25 \mathrm{~km} / \mathrm{h}$ \\
\hline 3 & 500 & 900 & 288 & 556 \\
\hline 4 & 350 & 600 & 234 & 428 \\
\hline 5 & 270 & 450 & 196 & 350 \\
\hline 6 & 220 & 360 & 170 & 296 \\
\hline 7 & 175 & 300 & 150 & 258 \\
\hline 8 & 160 & 255 & 134 & 228 \\
\hline \hline
\end{tabular}

\begin{tabular}{||c|c|c|c|c||}
\hline \multirow{2}{*}{$i \%$} & \multicolumn{2}{|c|}{$M O P(2014)$} & \multicolumn{2}{c||}{ Este estudio/This study } \\
\cline { 2 - 5 } & $\Delta \mathrm{V}=24 \mathrm{~km} / \mathrm{h}$ & $\Delta \mathrm{V}=40 \mathrm{~km} / \mathrm{h}$ & $\Delta \mathrm{V}=24 \mathrm{~km} / \mathrm{h}$ & $\Delta \mathrm{V}=40 \mathrm{~km} / \mathrm{h}$ \\
\hline 3 & 1100 & - & - & - \\
\hline 4 & 590 & 1800 & 970 & - \\
\hline 5 & 380 & 700 & 542 & - \\
\hline 6 & 310 & 510 & 390 & 1218 \\
\hline 7 & 260 & 420 & 308 & 658 \\
\hline 8 & 210 & 360 & 254 & 490 \\
\hline
\end{tabular}

Fig. 6. Critical grade lengths. 
Critical lengths of grade for design speeds are defined in the Roadway Design Manual of the Texas Department of Transportation (TxDOT) as well [17] (Fig. 7)

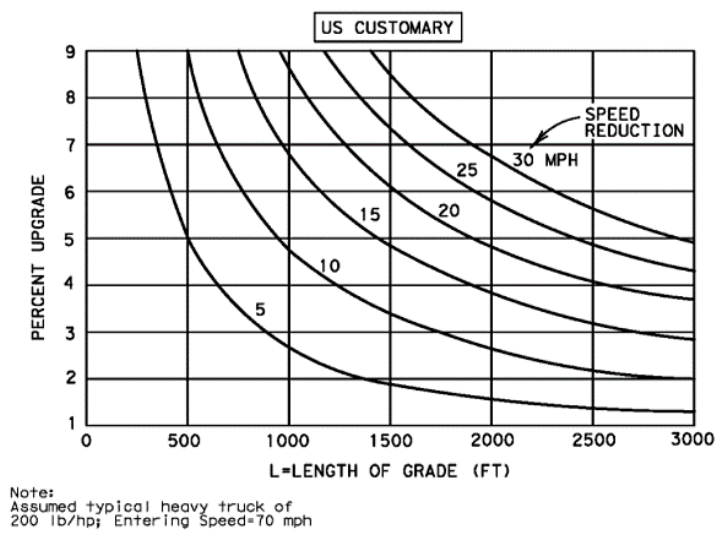

Fig. 7. Critical lengths of grade.

Other recent studies concentrate on the influence of ascending grades on the speed of heavy vehicles on two-lane rural roads. However, no new research for the dependence between speed and longitudinal inclination on highways is known to the author.

\section{Research methodology}

\subsection{Route selection and route characteristics}

The federal highway A72 between the cities Hof and Chemnitz, which is one of the oldest highways in Germany, was chosen for this study. In the 1930s, the A72 was originally planned as a "corner connection" of the basic network routes Berlin - Nuremberg and Frankfurt - Dresden. Highway A72 was rebuilt between 1990 and 1995, with its axis and gradients following closely the original planning of the 1930s. Such upgrading of existing highways with a near-existing route can lead to inconsistencies in the spatial alignment. In particular, higher longitudinal inclinations, which do not fulfill the requirements of the new regulations for this class of highway, can occur.

\subsection{Ascending and descending highway sections}

For assessing the dependence between longitudinal inclination and speed, all uphill and downhill highway sections were considered separately in both travel directions. For this purpose, the sections between the tangent intercept points in the longitudinal profile were used as an idealized model. Thus, one is always on the safe side when interpreting the results, since the reduction of the longitudinal inclination by the rounding radii of vertical curves is not taken into account.

To analyze the influence of the longitudinal inclination on the speed behavior, the mean value of the $85^{\text {th }}$ percentile speed was determined for each individual ascending and descending section. In order to take into account the free speed selection, all speed limited highway sections were excluded from the study.

The longitudinal inclinations were divided into three classes with a width of $2 \%$ as shown in Table 1. 
Table 1. Longitudinal inclination classes.

\begin{tabular}{|c|c|c|}
\hline $\begin{array}{c}\text { Class longitudinal } \\
\text { inclination }\end{array}$ & Ascending slope & Descending slope \\
\hline 1 & $0 \%<\mathrm{s} \leq 2 \%$ & $0 \%>\mathrm{s} \geq-2 \%$ \\
\hline 2 & $2 \%<\mathrm{s} \leq 4 \%$ & $-2 \%>\mathrm{s} \geq-4 \%$ \\
\hline 3 & $\mathrm{~s}>4 \%$ & $\mathrm{~s}<-4 \%$ \\
\hline
\end{tabular}

To investigate the speed changes as a function of the longitudinal inclination, the speed differences $\Delta \mathrm{V}_{85}$ between the speeds at the end $\mathrm{V}_{85, \mathrm{E}}$ and the beginning $\mathrm{V}_{85, \mathrm{~B}}$ of each individual ascending and descending section were calculated according to the model in Fig. 8.

$$
\Delta V_{85}=V_{85, E}-V_{85, A} \quad[\mathrm{~km} / \mathrm{h}]
$$

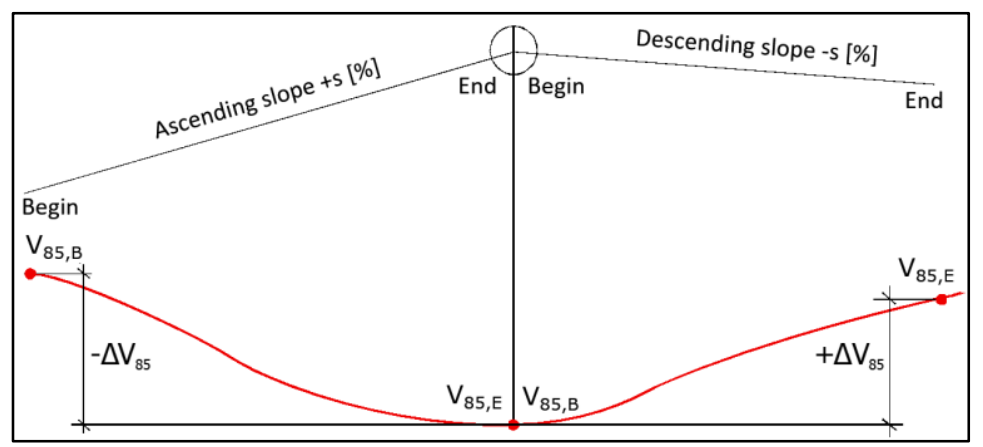

Fig. 8. Schematic representation for the calculation of speed differences $\Delta \mathrm{V}_{85}$.

\section{3 "Moving average" method}

The influence of longitudinal inclination on speed behavior was investigated using also the "moving average" method. A section with a fixed length of $500 \mathrm{~m}$ was moved in $100 \mathrm{~m}$ steps along the entire longitudinal profile of the tested highway. In each $500 \mathrm{~m}$ long section, the mean longitudinal inclination was calculated. All junction areas were excluded from the investigation to ensure that the correlations only apply to the free route.

\section{Results}

In order to ensure road safety, the German Highway Design Standards [18] specify maximum longitudinal gradients for each design class that should not be exceeded (Table 2). For the highest design class $1 \mathrm{~A}$ (EKA $1 \mathrm{~A}$ ), longitudinal inclinations below $4.0 \%$ are required.

Table 2. Maximal longitudinal inclination max s [\%].

\begin{tabular}{|c|c|}
\hline Design Class & $\begin{array}{c}\text { Maximal longitudinal inclination } \\
\text { max s [\%] }\end{array}$ \\
\hline EKA 1 A & 4.0 \\
\hline EKA 1 B & 4.5 \\
\hline EKA 2 & 4.5 \\
\hline EKA 3 & 6.0 \\
\hline
\end{tabular}


The distribution of the longitudinal gradients of the gradients for the federal highway A72 from both directions is shown in Fig. 9.

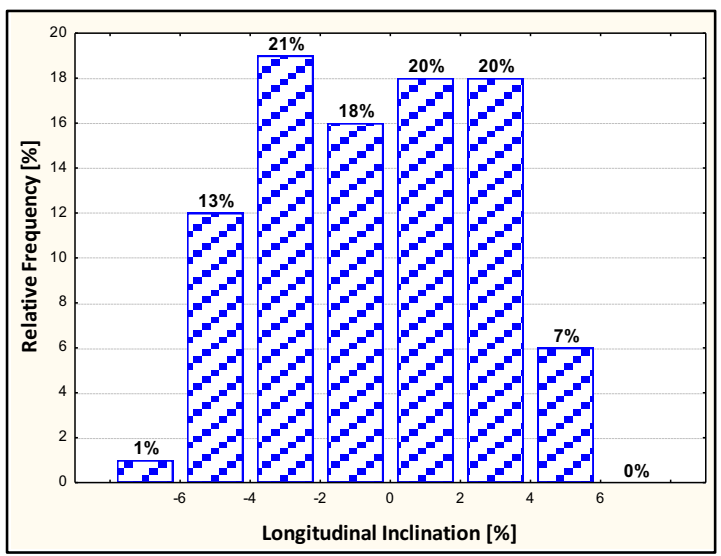

Fig. 9. Distribution of the longitudinal inclinations of the gradients on the entire highway.

It can be seen that the largest part (79\%) of all tested sections has gradients between $-4 \%$ and $+4 \%$ but despite this a considerably large proportion of gradients $(21 \%)$ is above $\pm 4 \%$, whereby the uphill gradients above $4 \%$ amount $7 \%$.

The results from the division of the longitudinal profile into ascending and descending sections are represented below. Fig. 10 shows that on ascending grades, both the $V_{85}$ and the $\mathrm{V}_{15}$ speeds decrease as the longitudinal inclination increases.
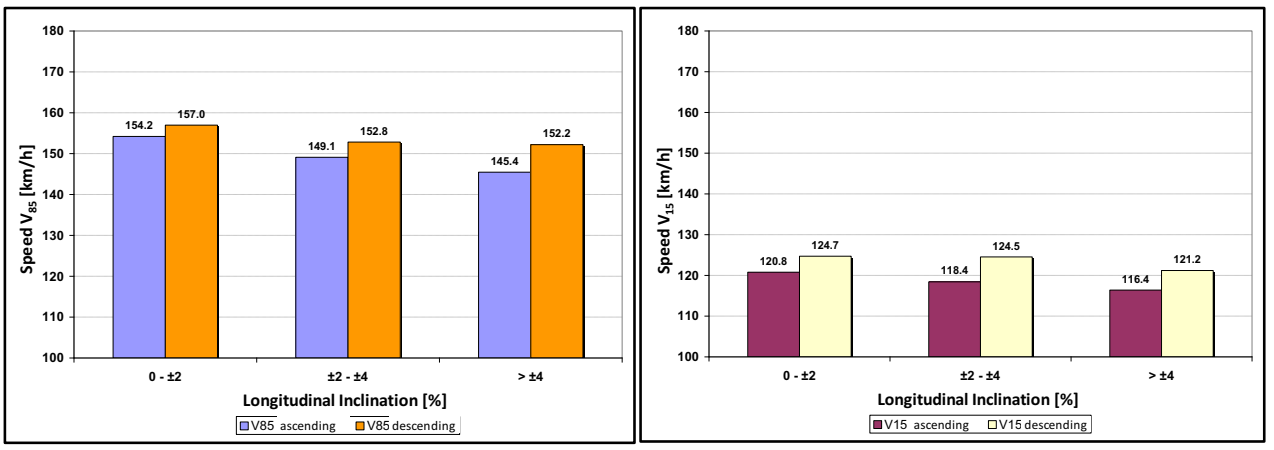

Fig. 10. Influence of the longitudinal inclination on the speeds $V_{85}$ (left) and $V_{15}$ (right) on uphill and downhill grades.

On uphill grades, the longitudinal inclination has a clear impact on the $\mathrm{V}_{85}$ speed. The difference between $V_{85}$ at slopes higher than $4 \%$ and $V_{85}$ at slopes between 0 and $2 \%$ is 8.8 $\mathrm{km} / \mathrm{h}$ (Fig. 10, left), whereas it is only $4,4 \mathrm{~km} / \mathrm{h}$ for $\mathrm{V}_{15}$ (Fig. 10, right). This leads to the conclusion that the magnitude of the longitudinal inclination on uphill grades has a stronger influence on the speed $\mathrm{V}_{85}$ than on the speed $\mathrm{V}_{15}$. On downhill sections (descending grades), the speeds are generally higher at all longitudinal inclination classes than on uphill sections (ascending grades). However, the differences between the percentile speeds $V_{85}$ and $V_{15}$ in all three longitudinal inclination classes on downgrades are negligible (Fig. 10) and it is obvious that the magnitude of the longitudinal inclination has no influence on $\mathrm{V}_{85}$ and $\mathrm{V}_{15}$ speeds.

To investigate the differences between the mean values of the speed differences at different uphill and downhill grades, the absolute values $\left|\Delta \mathrm{V}_{85}\right|$ were calculated. The speed changes within each individual section were neglected and the speed differences were 
calculated according to the idealized model shown in Fig. 8. The smallest absolute speed differences were recorded at longitudinal inclinations up to $2 \%$ (Fig. 11). This means that a balanced driving style with smaller accelerations or decelerations is present at such inclinations on both upgrades and downgrades. At a longitudinal inclination between $2 \%$ and $4 \%$ the mean absolute speed differences on uphill sections increase by $52.2 \%$ compared to the mean differences in the first longitudinal inclination class below $2 \%$. At longitudinal inclinations between $4 \%$ and $6 \%$ the speed difference is $113 \%$ higher. No correlation was established between the speed differences and the magnitude of the longitudinal inclination on downhill slopes.

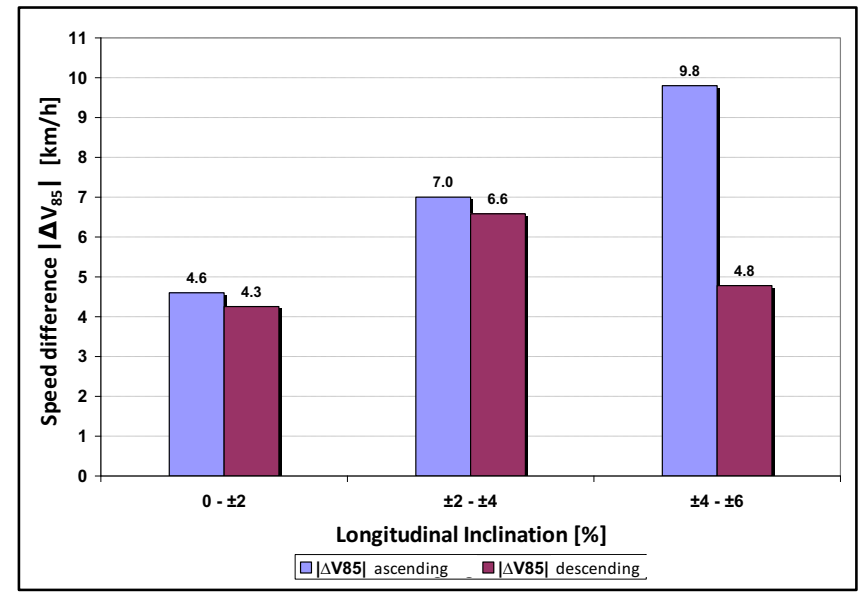

Fig. 11. Absolute Speed Differences $\left|\Delta \mathrm{V}_{85}\right|$.

The results from the "moving average" method showed that with increasing longitudinal inclination, a significant reduction in speed is present on ascending sections. The speed $\mathrm{V}_{85}$ averaged $154 \mathrm{~km} / \mathrm{h}$ at a longitudinal inclination lower than $2 \%$ and is reduced by $16.7 \mathrm{~km} / \mathrm{h}$ at longitudinal inclinations higher than $4 \%$ (Fig. 12). Particularly at large longitudinal inclinations, a significantly higher speed drop could be expected. The speed level of the $V_{85}$ was generally higher on descending grades. However, with increasing longitudinal inclination a negligible decrease in speed was observed. The difference between the first and the third longitudinal inclination class was only $3.5 \mathrm{~km} / \mathrm{h}$.

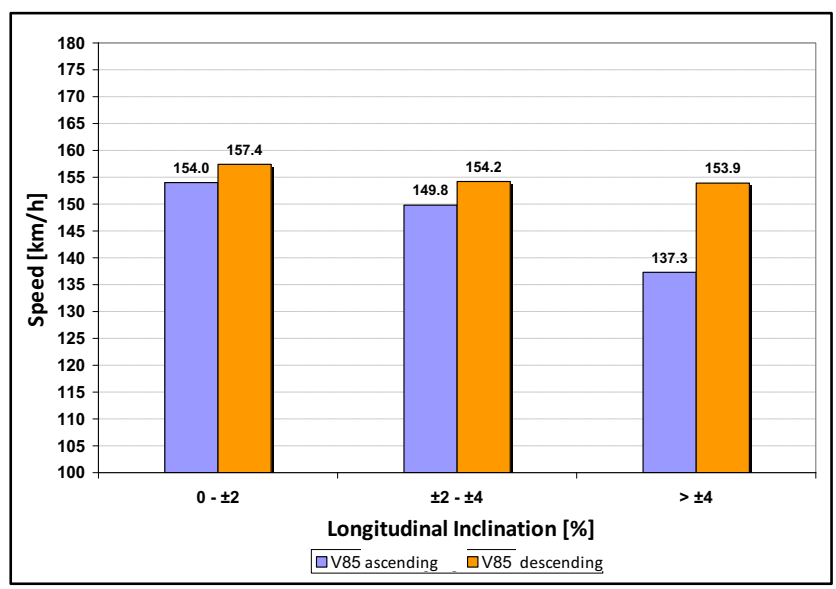

Fig. 12. Influence of the longitudinal inclination on $\mathrm{V}_{85}$ according to the "moving average" method. 
While an increasing mean deceleration was calculated at increasing longitudinal inclination on ascending grades, an almost equal acceleration can be observed in each longitudinal inclination class on descending grades (Fig. 13).

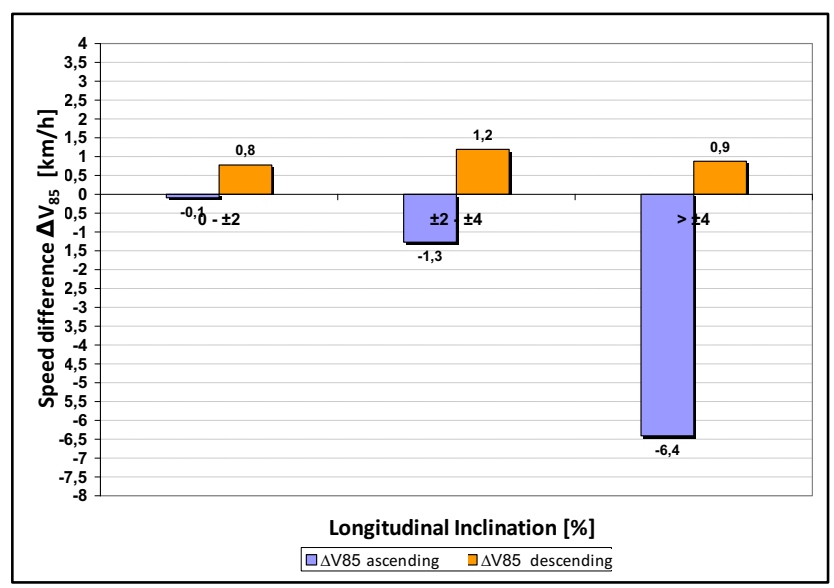

Fig. 13. Relationship between longitudinal inclination and speed difference $\Delta \mathrm{V}_{85}$ on uphill and downhill sections without speed limits.

It was stated that the length of the grades on highways also influences the speed differences $\Delta \mathrm{V}_{85}$ at a high extent. While a speed reduction of only $4.4 \mathrm{~km} / \mathrm{h}$ was calculated for ascending grades with a $4 \%$ slope and a length up to $500 \mathrm{~m}$, this reduction was $6.6 \mathrm{~km} / \mathrm{h}$ for lengths of grades between 500 and $1000 \mathrm{~m}$. The speed differences were higher $(7.2 \mathrm{~km} / \mathrm{h})$ at the same slope within sections longer than $1000 \mathrm{~m}$.

\section{Conclusions and recommendations}

As stated in previous research, it has also been confirmed in this study that the magnitude of the longitudinal inclination has a considerable effect on the speeds $V_{85}$ and $V_{15}$ on ascending grades. However, this influence is more pronounced at speeds $\mathrm{V}_{85}$ than at speeds $\mathrm{V}_{15}$. For gradients above $4 \%$, higher speed reductions and higher speed differences $\Delta V_{85}$ have been detected, compared to those at gradients below $2 \%$. For safety reasons, for a homogeneous driving behavior and for a reduction of the pollutant emissions, it is therefore recommended to design gradients with ascending slopes below $4 \%$. No correlation has been found between the speed differences and the magnitude of the longitudinal inclination on descending grades. An important result is that the length of the grades on highways also influences the speed differences at a high extent. While the speed reduction at ascending grades with a $4 \%$ slope with a length up to $500 \mathrm{~m}$ was only $4.4 \mathrm{~km} / \mathrm{h}$, this reduction was $6.6 \mathrm{~km} / \mathrm{h}$ for grades with a length between 500 and $1000 \mathrm{~m}$ and $7.2 \mathrm{~km} / \mathrm{h}$ within grades longer than $1000 \mathrm{~m}$. Ascending highway sections with a slope under $4 \%$ and a length under $500 \mathrm{~m}$ are therefore recommended to ensure a homogeneous driving behavior, to reduce road users' costs and to minimize pollutant emissions.

\section{References}

1. W. Durth, Ein Beitrag zur Erweiterung des Modells für Fahrer, Fahrzeug und Straße in der Straßenplanung, Dissertation an der Technischen Hochschule Darmstadt (1972) 
2. J. Dilling, Fahrverhalten von Kraftfahrzeugen auf kurvigen Strecken, Forschung Straßenbau und Straßenverkehrstechnik, Heft 151, Bonn - Bad Godesberg (1973)

3. J. Fiedler, Bewertung von Landstraßentrassen mit Hilfe von Geschwindigkeitsbildern, Forschungsarbeiten auf den Straßenwesen, Heft 69 (1967)

4. K.-H. Trapp, Untersuchungen über den Verkehrsablauf auf Landstraßen, Forschung Straßenbau und Straßenverkehrstechnik, Heft 113, Bonn - Bad Godesberg (1971)

5. K.-H. Trapp, F.-W. Oellers, Streckencharakteristik und Fahrverhalten auf zweispurigen Landstraßen, Straßenbau und Straßenverkehrstechnik, Heft 176 (1974)

6. G. Köppel, H. Bock, Fahrgeschwindigkeit in Abhängigkeit von der Kurvigkeit, Forschung Straßenbau und Straßenverkehrstechnik, Heft 269, Bonn - Bad Godesberg (1979)

7. Chr. Lippold, Weiterentwicklung ausgewählter Entwurfsgrundlagen von Landstraßen, Dissertation, TH Darmstadt (1997)

8. G. Steierwald, M. Buck, Geschwindigkeit verhalten auf einbahnigen Außerortsstraßen in Abhängigkeit von baulichen, betrieblichen und verkehrlichen Randbedingungen,

Forschung Straßenbau und Straßenverkehrstechnik, Heft 621, Bonn - Bad Godesberg, (1992)

9. W. Durth, Einflüsse der Erhöhung der Geschwindigkeiten und Beschleunigungen von Fahrzeugen auf die Entwurfsgeschwindigkeit, Forschung Straßenbau und Straßenverkehrstechnik, Heft 385, Bonn - Bad Godesberg (1983)

10. F.-W Oellers, Untersuchung über den Einfluss der Fahrstreifenbreite auf den Verkehrsablauf auf Richtungsfahrbahnen, Forschung Straßenbau und Straßenverkehrstechnik, Heft 211, Bonn - Bad Godesberg (1976)

11. U. Brannolte, Verkehrsablauf an Steigungsstrecken von Richtungsfahrbahnen, Forschung Straßenbau und Straßenverkehrstechnik, Heft 318, Bonn - Bad Godesberg (1980)

12. G. Köppel, Entwicklung einer Bemessung von Kurvenradius, Kurvenquerneigung und Haltesichtweite in Abhängigkeit von der Fahrbahngeometrie, Forschung Straßenbau und Straßenverkehrstechnik, Heft 429, Bonn - Bad Godesberg (1984)

13. P. Reichelt, Die Steuerung von dynamischen Verkehrsbeeinflussungsanlagen mit Hilfe der Reisezeit, Dissertation, Aachen (1980)

14. B. Hartlich, Geschwindigkeitsverhalten auf Bundesautobahnen, Straßenverkehrstechnik, Heft 2 (1981)

15. A. Polus, J. Craus, M. Livneh, Determination of longitudinal grades on rural roads, Transportation research circular (1998)

16. T. Echaveguren, D. Carrasco, Estimation of critical length in ascending grades of twolane rural roads, Revista Ingeniería de Construcción, Vol. 30, No. 1 (2015)

17. Texas Department of Transportation (TxDOT), Roadway Design Manual (2020)

18. Forschungsgesellschaft für Straßen- und Verkehrswesen (FGSV), Richtlinien für die Anlage von Autobahnen, ISBN: 978-3-939715-51-1 2007, Köln (2008) 